\title{
De-contextualisation fuels controversy: the double- edged sword of humour in a hybrid media environment
}

\author{
Sara Ödmark \\ Mid Sweden University, Sweden \\ sara.odmark@miun.se
}

\begin{abstract}
Humour has a unique way of delineating social boundaries, and comedy can function as a double-edged sword; it can strengthen bonds and bring people together, or divide through provocation and violation of social norms. As a consequence, humour controversies are telling events that contain the possibility of highlighting cultural and political sensibilities - even more in the current political landscape, with increasing media fragmentation. This study analysed four humour functions through the theoretical lens of media framing, via three cases of humorous content that caused controversies in the Swedish news media. These cases were one divisive radio roast of a politician, one $T V$ satire segment that was received as racist, and one audio podcast with young women who challenged a Swedish political consensus climate. Framing is the power of media to select and highlight certain aspects of issues, and by extension, shape public opinion. By subjecting the media coverage of these three controversies to a qualitative content analysis, the framing was examined and discussed in the light of four humour functions: identification, clarification, enforcement, and differentiation (Meyer 2000). Furthermore, the study examined the media context and the role it played in the framing of the controversies. One main finding was that the most uniting humour function of identification could be transformed into the most dividing humour function of differentiation through a shift in media context.
\end{abstract}

Keywords: political comedy, humour functions, framing, humour scandals, contextualisation

\section{Introduction}

It has been said about political comedians that they have the status of public philosophers, as they bridge the gap between philosophers and the public (Marra 2018: 162). In relation to societal events and issues, comedians engage in a process of discussing and reinterpreting, twisting and turning, seeking unique and surprising angles of arguments through the use of humour. This makes a joke an exchange not only between the comedian and his/her audience, but also between the comedian and society at large (Douglas 1999; Quirk 2015). 
Humour can delineate social boundaries: creating in-groups and out-groups, inclusion and exclusion, those we laugh with and those we laugh at. The political comedian can strengthen bonds and bring people together in laughter, and simultaneously divide through provocation, limit stretching, and violation of social norms and conventions (Billig 2005; Kuipers 2008: 366). As a consequence, humour controversies become telling events that contain the possibility of highlighting cultural sensibilities of any given society. Their conflicting qualities make humorous transgressions possible catalysts of larger public debates (Kessel \& Merziger 2012), and they are therefore helpful for investigating how humour functions in a political setting.

It has been 20 years since Meyer (2000: 310-331) explored the uniting and dividing functions of humour and proposed four humour functions: identification, clarification, enforcement, and differentiation. In the intervening decades, the media landscape has changed dramatically due to increased digitalisation. Lately, with the rise of social media, the notion of the audience has been redefined (Weitz 2016: 2), and in a media landscape with increasing fragmentation and polarisation, the double-edged sword of political humour has gained scholarly attention (Bruun 2012; Jones 2013; Kumar \& Combe 2015).

Although controversies are suitable research topics for analysing the political functions of humour and its relationships with societal norms, they are understudied (Attardo 2008; Bell \& Attardo 2010: 423; Bell 2009; Kuipers 2006). The current study aims to contribute to the field and add an additional layer of richness by investigating non-Anglophone humour. Since the public reception of and impacts of humorous provocation do differ based on culturally constructed conceptions, collecting data from different cultural contexts is vital to academic understanding of political humour. The controversies analysed in this study originate in Sweden, a country considered to be in the forefront of digital media transformation. Among 28 countries in the EU, Sweden, where 90 per cent of the population possesses smartphones (Davidsson et al. 2018: 14), is ranked second when it comes to the level of digitalisation. ${ }^{1}$ Regarding cultural sensibilities, Swedish people are frequently represented as conflict-avoiding and consensusseeking people who value compromise and commonality, with the media acting as a social glue that contributes to their cohesion (Syvertsen et al. 2014). This makes media framing of humour controversies particularly notable.

This study aims to analyse the uniting and dividing humour functions through the theoretical lens of media framing, via three cases of humorous transgressions that caused controversy in the Swedish news media. Through a qualitative reading of the material, the findings will nuance and enlighten the understanding of political humour functions in contemporary media debate.

The article proceeds with a presentation of the theoretical and methodological frameworks, including the research questions. Following that, the controversies will be presented and analysed, after which a summary will conclude the findings.

\section{The double-edged sword of humour}

Since the days of Plato, humour has been described as a mixed feeling of the soul, a sense that consists of both pleasure and pain (Plato 1961). This dualistic nature is termed the paradox of humour or the double-edged sword (Attardo 1994; Meyer 2000: 310). When reviewing humour origin research, three major humour theories emerge: the release or relief theory, the incongruity theory, and the superiority theory (McGhee \& Goldstein 1972; Morreall 1983; Raskin 1985; Berger 1999; Meyer 2000). However, these theories may overlap, and why a message is humorous can be explained differently depending on which theoretical glasses the message is interpreted through (Meyer 2000: 315). Therefore, humour theories can helpfully be understood

\footnotetext{
${ }^{1}$ Digital Economy and Society Index, European Commission (2018).
} 
not as a set of clear paradigms but more as models which help us interpret human interactions through joke and laughter (Quirk 2015). Applying a communicative approach to these three theories of humour origin, Meyer presented four basic functions of humour in communication (Table 1) - two that unite communicators (identification and clarification), and two that divide one set of communicators from others (the enforcement and differentiation functions). Identification serves to build group cohesiveness. Using self-deprecating humour to ally yourself with the audience is an example of identification (Chapel 1978), while clarification helps communicators encapsulate their views and present their positions. In both cases, you laugh together with others. Enforcement, on the other hand, is about pointing out violation of norms, and differentiation requires contrasting yourselves against opponents. This could be described more as laughing at others.

Table 1. Origin theories of humour with corresponding rhetorical functions (from Meyer 2000: 317)

\begin{tabular}{|l|l|}
\hline Humour theory & Humour function \\
\hline Relief & Identification \\
\hline Incongruity & $\begin{array}{l}\text { Clarification } \\
\text { Differentiation }\end{array}$ \\
\hline Superiority & $\begin{array}{l}\text { Identification } \\
\text { Enforcement } \\
\text { Differentiation }\end{array}$ \\
\hline
\end{tabular}

Another aspect of the dualistic nature of humour is that humour can be directed both upwards and downwards; it can be used to exercise power but also to express resistance (Kuipers 2014: 710). Politically, humour holds the possibilities of being a social lubricant, sandpaper and/or glue; it breaks ice, conveys criticism less contentiously, and appeals to common sentiments (Basu 1999). Political humour can endorse certain standpoints as it criticises others, and create sympathy as it ridicules (Higgie 2017). As cultural expressions as well as critique, humour has been said to be an essential resource for sustaining public culture (Lynch 2002; Hariman 2008).

When placing the humour functions along a continuum, identification is the most uniting function, followed by clarification, enforcement, and differentiation, where enforcement and differentiation are more dividing functions (Meyer 2000: 318). The different functions of humour are, however, elusive to examine. They often intersect and are hard to separate (Palmer 1994; Ziv 1984). One way to approach the ambivalence and fluidity of humour functions is to look for reflections of them in a fixed context, such as media material. This essay will therefore focus on reactions to humour, and examine news media framing for expressions of the four humour functions.

\section{Media framing and humour controversy}

The digitalised, fast-moving social media landscape adds complexity to the encoding and decoding of humorous messages. Social media has dissolved boundaries between private and public spheres, and the increasing media fragmentation and audience segmentation might lead to new forms of political socialisation (Mancini 2013: 51). Typing and reading are not the same as talking and listening, and the digital world reshapes aspects such as comedic timing and joke dissemination (Weitz 2016: 2). If an audience is to experience identification, meaning that if humour should serve to strengthen commonality and shared meaning, the audience needs to be sympathetic to and quite familiar with the topic of humour (Meyer 2000: 318). Appreciation for 
humour also increases if the audience is in a humorous mode - a non-serious, playful mood in which one does not take things literally (Mulkay 1988). If mediation puts up barriers for this, for instance, by de-contextualising or re-contextualising humour when it spreads on social media, it increases the chances of possible misunderstandings and sources of offence (Rose 2014).

The political comedian does not shy away from polarising topics. These issues are sensitive and might be difficult to address, but humour and taboo are closely related, and sensitive topics have humorous potential (Kuipers 2006). Some comedians who tackle news and current affairs in their material resemble traditional journalists in their topics and angles, but differ from them in style by employing a more personal and emotional framing (Ödmark 2018). This emotional limit-stretching and potential line-crossing can lead to controversy. Controversies can influence the news media agenda; for instance, studies on election coverage on the American TV show Saturday Night Live have shown that the traits of the satirical portrayal of the vice-presidential candidate Sarah Palin were used in the traditional news media as the ground for commenting on her performance (Abel \& Barthel 2013; Michaud Wild 2015). This demonstrates the way that alternative news commentary, such as political comedy, is being incorporated into the mainstream news environment.

The material analysed in this study was media coverage in the Swedish news media. Media coverage can mould certain positions around issues in the public sphere, since the media framing define the story's meaning and thereby shape people's interpretations (Entman 1993; Hallahan 1999). This makes the media matter when it comes to how comedy, or culture and the arts in general, can have a political function (Dahl 2019: 211). Framing involves a communication source presenting and defining an issue (De Vreese 2005). It is a well-established theoretical framework in political communication scholarship (Scheufele \& Tewksbury 2007) and has been an important concept in media studies for decades, since one of the main functions of the media is to select and highlight certain aspects of an issue (Bryant \& Miron 2004). The framing concept can serve as an illuminating mode of analysis since it offers helpful orientation for the study of political humour discourse, functioning as a valuable tool for gaining a more precise conception of the political humour domain (Peifer 2013). In this study, analysing the framing of humour controversies will offer insights into how the humour functions of political comedy are reflected in media coverage.

Based on this theoretical framework, the following research questions have been proposed:

RQ1: How are the humour controversies being framed in the media coverage?

RQ2: How does the framing of the controversies relate to identification, clarification, enforcement, and differentiation as four humour functions?

RQ3: What is the media context of the controversy, and how is that reflected in the framing?

\section{Method and material}

This study investigated the expressions of humour functions through the framing of humour controversies in the Swedish news media. Three cases were selected, and content analysis was employed to study their media coverage. The controversies were strategically selected based on the following criteria: a) they were media products with humorous intent, b) they were similar in form but representing different media platforms, and c) they had recently gained attention and criticism in the Swedish news media. The time period chosen was the fall of 2018, and the media format was either video or audio: a radio segment (from the radio show Morgonpasset $i$ $P 3$ ), a TV satire segment (from the TV show Svenska Nyheter), and an independently produced audio podcast (Della $Q$ ). 
The data was collected through keyword searches on Retriever, a database that covers a vast collection of media outlets. Though not comprehensive, it offers an extensive archive for the Swedish press, both analogue and digital, national and regional. All major newspapers, as well as news websites from public broadcasting companies, were included in the material. The selected keywords were the names of the humour outlets involved in the controversy (Morgonpasset, Svenska Nyheter, Della Q) paired with other main actors, for example, Morgonpasset + Jimmie Akesson (the politician at the centre of that controversy). The broad keyword search helped identify a period for each case, where the media coverage was mostly concentrated. The spans ranged between two weeks and about six weeks after the starting point of the controversy. This provided an initial data set of around 700 news items. The collected news items were sifted manually to exclude irrelevant content. Examples of excluded items were duplicates, such as when identical content provided by news agencies was published in several newspapers, and articles that merely referenced the selected keywords in passing, without additional commentary. This sorting also provided an overview of the material, after which the selected periods could be limited further, to key dates with high intensity of media coverage. In total, the number of articles subjected to in-depth analysis was 225, ranging from 37 articles devoted to the least covered controversy (C) to 98 articles referring to the most covered controversy (B).

Since this study was less interested in the frequency of different predefined frames, and more interested in the complexity and nuances of the media framing, a qualitative approach was thereafter chosen. The aim of qualitative content analysis is to preserve the advantages of quantitative content analysis but also provide a more qualitative textual interpretation (Kohlbacher 2006). Following an approach inspired by Mayring (2014), each news media item was summarised into inductively generated thematic frames. This called for the material to be coded in a process that reduced the media text to its essential content. This approach is suitable for qualitative content analysis since it combines the principles of openness and systematic methodology (Kohlbacher 2006), and it has previously been employed in examining political entertainment material (Lichtenstein et al. 2018). The procedure used in this case was inductive category formation (Mayring 2014: 79), where the material itself dictates the coding, in contrast to proceeding from theoretical considerations. By condensing the main arguments of the articles into category labels, responding to how the humour controversy in question was described and how the media context of the controversy was described, a series of frame categories relating to the research questions emerged. These frame categories were grouped together and thematised, after which the material was recoded to identify the most prevalent frame themes. Finally, the main frame themes were examined against the four humour functions, which concluded the analysis. This made for a combination of inductive and deductive methodologies, asserting systematic analysis while ensuring flexibility.

It is important to note that the findings should not be seen as all-encompassing of the possible media frames regarding humour controversies. The three cases serve as examples for illustrative purposes to facilitate a discussion. In the analysis of framing, there might also be a risk of subjectivity in assessment due to a somewhat ambiguous conceptualisation (Borah 2011), which should be considered when reviewing the data presentation. The coding was, however, conducted by a single coder (the author), which is beneficial in qualitative content analysis since inter-coder discrepancies can be avoided (Mayring 2014).

The controversies will be presented in chronological order. 


\section{Findings}

\subsection{Controversy A: The roasted party leader}

On the morning of 29 August 2018, shortly before the Swedish national election, party leader Jimmie Åkesson was a guest on the public service radio show Morgonpasset $i$ P3. The channel P3 was at the time the Swedish public service radio station aimed at young adults. Jimmie Åkesson is a controversial figure in the Swedish political landscape. He is the leader of the Sweden Democrats (SD), a right-wing political party that has been high-profile in Swedish public debate since the election of 2006, due to its anti-immigration agenda and populist rhetoric (Hellström et al. 2012). The Sweden Democrats got 18 per cent of the votes in the 2018 election, making it the third largest party in the parliament. The party attracts constant media attention, and news concerning Åkesson is often among the most shared and interacted with on social media in Sweden (Wadbring \& Ödmark 2014: 42).

One of the segments on the radio show in question was a live studio roast, performed by a satirist from a political satire show broadcast on the same public service channel. A roast is a comedic form in which a person is subject to jokes, sometimes quite tendentious, at the individual's expense. This was a regular part of the election coverage of the morning show and was done to all party leaders in the parliament. The satirist started the roast by calling Åkesson a traitor, since

he doesn't love our country as much as you would expect. Did you know for instance that he didn't root for Sweden in the last World Cup, but for Saudi Arabia? You see they could return 5,002 times the money if betted on, and Jimmie couldn't resist a temptation like that, being a gambling addict.

(Sveriges Radio, 29 August 2018)

This referenced both the nationalist discourse around the Sweden Democrats and previously reported gambling issues of Åkesson. Other jabs of the roast revolved around Åkesson fluctuating in weight, being "whiny," and not having had much sex in his youth, "at least not with consent." Åkesson reacted strongly to the segment, saying on-air that he was appearing on a "crap-channel" and that if he were in charge, it would be shut down. All major news outlets reported on this event, and the reactions and debate surrounding it constituted a developing news story for the following days.

Looking generally at the media coverage, and especially immediately after the event, the dominant frame was how this was an attack on the media by Åkesson. Regardless of the success or failure of the humour, this was regarded as an inappropriate statement to make according to the framing, and by extension a threat to democratic values. Studies have found humour controversies to share similarities with other forms of political, sexual, and financial scandals (Thompson 2000; Ekström \& Johansson 2008). Common to all is a transgression of norms, values, or moral codes. Looking at the initial media framing, the controversy could be considered less of a humour scandal and more of a talk scandal, since the roast in itself was not being reported as the main transgression, but instead most of the coverage highlighted the reactions and statements of the party leader. Let us therefore first examine this main framing before returning to the humour functions.

A talk scandal, in this case a first-order talk scandal, is when there is a verbal transgression in the media (Ekström \& Johansson 2008: 62). The central question is what people in a certain position are allowed to say and how they should behave in public. In this case, the transgression was framed as being made by Åkesson, in part by emotional overreaction and inappropriate language, but mostly by censuring the channel and expressing his intention to silence it. 
This sparked a debate on independent journalism and the role of public service broadcasting media, with strong reactions from other politicians, media scholars, and journalists. In political media framing, especially during election campaigns, there are two common umbrella terms under which frames can be placed: game frames, where focus is on who is winning or losing, and issue frames, where there is more focus on political substance (Aalberg et al. 2011). Issue frames were in this case more prominent than game frames, meaning that the media framing was not particularly focused on what this meant for the horse race of the election. Instead, the event was framed as a political move by Åkesson that had implications from a political issue perspective. This corresponds to previous research on Swedish media coverage of the political sphere (Strömbäck \& Dimitrova 2006: 142). One example of issue framing was how the event was put into an international context as part of an ominous "anti-media trend:"

The current situation has apparently changed enough for Åkesson to have the nerve to speak this openly in the middle of an election campaign. It makes you shiver. But if the president of the US can make CNN and The New York Times his main enemies, why would SD hesitate?

(Kvällsposten, 30 August 2018)

Regardless of this being more a talk scandal than a humour scandal, there were still reflections of humour functions present in the media material, mostly those of enforcement and differentiation. The roast itself was referred to with occasional quotes or links to the segment. When given value descriptions, they were critical: the roast was called raw, crude, and inconsiderate. The references to his appearance got highlighted in headlines, such as "Weightmocked - why Åkesson wanted to scrap P3" (Sallinen 2018). It was also mentioned in suggestions on how Åkesson should have reacted, that he should have calmly said he expected his party to be satirised and not his weight. When interviewed afterwards, Akkesson framed the roast as proof of the channel's political bias, said he was offended, and called it "left-liberal rubbish." Enforcement was seen within the focus on norm violations, both with regards to the roast and to the reaction by Åkesson. Differentiation was reflected in the clear divide created between the politician, representing the party, and the satirist, representing the media organisation. Åkesson even said he considered the radio channel to be a "political opponent," a quote that was emphasised in many of the articles.

Another humour-specific reference that appeared in the framing was the notion of rightwing populist affinity for satire as a rhetorical device.

Åkesson was not amused by the segment, which is interesting in itself since many of his supporters on social media like to use satire to attack opponents, and when criticised for crossing lines of for instance hate speech their defence is "Aren't you allowed to joke in this country or what?"

(Falköpings Tidning, 6 September 2018)

This illustrated how the use of humour can be weaponised by a group through enforcement and differentiation, but when being confronted, the critique might be dismissed using the "just a joke"-excuse. However, when the in-group is subjected to similar treatment from outsiders, the same argument might fail to gain legitimacy. For an audience member, the perception of this incident came down to his/her political affiliation and previous attitudes held towards Åkesson and his party. A political opponent would easily experience identification and clarification with the satirist, while a political supporter would identify with Åkesson - transforming the rhetorical functions of the roast into enforcement and differentiation.

This duality of identification could be observed in the way both critics and defenders of Åkesson talked about him losing his mask due to the roast. The critics expressed this in terms of dropping a political façade, "saying what he really meant," and revealing his true feelings and intentions for public service broadcasting media. The defenders, on the other hand, 
referenced it as Åkesson understandably losing his temper, and being exposed to the roast was framed as an explanation for his statements. According to these defenders, the political implications of his statements were being overstated:

Funny? Well. Crude? Definitely. It's strange how you believe a party leader should gladly accept the lowest attacks. Perhaps Jimmie Åkesson quite simply lost his politician-face for a second when appearing in P3? Maybe he, oh shock and horror, became a bit sulky? [...] Ockham's razor tells us that the simplest explanation usually is true. Does Jimmie Åkesson wish to abolish free speech and press? Does he want to dictate radio content? Does he want to be the Orban of Sweden? Jimmie Trump? Or did he take offence with the crude satire and express some anger?

(Svenska Dagbladet, 30 August 2018)

The media context was also visible in the coverage. Some of the reactions to the roast were affected by de-contextualisation when the news spread on social media, since the fact that other party leaders also had been roasted became less apparent. Some people assumed the treatment was unique to Åkesson, or at least uniquely harsh, conforming with a pre-existing supporter narrative about the public service broadcasting media treating the Sweden Democrats unfairly for political reasons. However, the roast was in the media also called "propaganda for SD," since it created sympathy with "those bullied" - pointing to the possibility of differentiation against a certain group causing stronger identification with said group.

The very practice of a roast as a media format was also questioned.

Political satire can be brilliant, but when it's mostly "locker room talk" à la Trump, it's just crude. Still, the party leaders kindly agree to such events and laugh perhaps a bit forced at ever so rotten jokes. It is self-degrading, but also worse. It is voter-contempt.

(Norrköpings Tidningar, 30 August 2018)

Performing a roast of this kind was described as a low form of satire that came as a result of a fragmented debate climate marked by fake news, hate, threats, and other transgressions that modern politicians are forced to comply with (Stigsson 2018). Social media was blamed for fostering bad or questionable satire, creating a trend that the roast of $\AA$ kesson followed.

Moving on, we look at a controversy of a different, perhaps more conventional format: the TV news satire segment.

\subsection{Controversy B: The Chinese stereotypes}

Modelled after American TV programmes such as Last Week Tonight with John Oliver, the satirical news show Svenska Nyheter premiered in 2018 on Swedish public service TV. In September 2018, the show aired several segments commenting on a news story about Chinese tourists refusing to leave a hotel after making reservations for the wrong date, leading to an altercation between the tourists and Swedish police. One of the satire segments consisted of a manufactured information video meant to parody Swedish prejudices of China and Chinese stereotypes. It included statements such as "In Sweden, we eat with a fork and knife," "we don't defecate outside historical buildings," and "if you see someone walking a dog, it's not their lunch." The video was dubbed in Chinese and posted to Youku, a Chinese social media site similar to YouTube. The negative reactions were immediate, and the show was accused of racism.

The media framing of this controversy could be divided into three frame themes: those addressing the cause of the controversy, those addressing the content in itself, and those addressing the consequences of the controversy. A prevalent frame in the material regarding both the cause of the controversy and the consequences was that the incident connected to a wider political context: it was put forward as a symptom of pre-existing tension between the two 
countries and that the specific segment was merely used as a tool to forward political agendas. Based on previous research, there is little doubt that the media framing of political matters has a strong tendency to focus on conflict (Patterson 1993; De Vreese et al. 2001), and employing humour content to push specific national agendas corresponds with how politicians and activists used the Danish cartoon crisis (Ammitzbøll \& Vidino 2007; Klausen 2009). A political issue specifically mentioned in the media coverage was the Chinese government's detention of Swedish publisher Gui Minhai:

The problem is that China wishes to move focus from the issue of Gui Minhai. Initiating a debate on racism is perfect for them. Then people will be talking about this for a few weeks, asking themselves "is this racist?", instead of focusing on the real issues.

(SVT Nyheter, 24 September 2018)

A focal point in that framing was how China was the main transgressor, by wanting to cover up bigger issues, and/or by overreacting to humour, and/or by attacking free speech. On the other hand, there were also frames pointing to the satirical show as the faulty actor. This was connected directly to the media context: the transgression and the cause of the failing of the humour was here identified as being taken out of context in general and being posted on Youku to be specific. If you watched the entire broadcast, the set-up for the parody video included a rationale about these matters. The main point of the introduction was to problematise how expressions of Sinophobia are more accepted in Swedish society compared to other forms of prejudice and discrimination, but the set-up was not uploaded to Youku. In the media framing of the controversy the segment was described as inexplicable, a mistake, and a simple stunt to stir up Chinese reactions:

it ends with a segment which, out of context, can only be perceived as severely racist. [...] It is difficult to imagine the same segment in Swahili including blatant insults towards black people.

(Upsala Nya Tidning, 26 September 2018)

The coverage of the humorous segment in itself could be placed on a scale of criticism ranging from defences of the content (it did not have racist intent, it was directed towards Swedes and not the Chinese) to censures, calling the segment irresponsible and culturally insensitive. The former responds well to the humour function of identification - aiming the humour towards Swedish ignorance is a form of self-deprecation - while the latter reflects enforcement and differentiation. Reflections of the clarification function were not as apparent.

Enforcement serves its purpose when deviation from social norms is held up for ridicule. Laughter in this case is invoked to discipline those who are not seen as properly following the rules of a social group (Duncan 1962; Meyer 2000: 320). According to the critical framing of the content, this was how the segment read; the Chinese violations of Swedish social norms were the basis of the humour, not the ironic portrayal of Swedish misconceptions of the Chinese. However, there were examples of frames where this seemed irrelevant: the handling of the controversy by the Swedish television company was scrutinised and considered as "cowardly," because of the decision to remove the content from Youku after the reactions.

An example of how the differentiation function was being expressed can be found in the debate article "It's just a joke - and apparently we Chinese lack a sense of humour" (Tang 2018). In it, the author Aili Tang described how the satire segment for her and other Chinese people living in Sweden had made the country feel "colder and less welcoming." There are clear connections between humour and culture, and humour from cultures distant to your own often seems coarse or incomprehensible (Apte 1985). In political humour, and ethnic jokes in particular, identification is of prime importance for appreciation (Kuipers 2006: 149), and since the author in this case could not identify with the content or intent of the joke, it caused a divide 
between her and her fellow residents. The identification function was transformed into the differentiation function.

The satirists behind the TV show had a humble approach to the controversy when giving statements in the news media material. While they stressed that their intent was to mock the Chinese government and to raise awareness of how little knowledge and interest Swedes have of the country, they admitted to something going wrong in this case. The segment being recontextualised on Youku without proper explanation was identified as the main problem. Ironically, it seems the satirists wanted to shed light on Swedish ignorance about Chinese cultural sensibilities - and instead proved themselves guilty of said ignorance.

\subsection{Controversy C: The podcast}

During the fall of 2018, the podcast Della $Q$ was the subject of an ongoing debate mostly in the culture pages of Swedish newspapers. Della $Q$ premiered in July 2018 and quickly gained media attention. The audio podcast was made by satirists, artists, and media personalities Anna Björklund, Moa Wallin, and Bianca Meyer, and consisted of weekly discussions on a variety of societal topics in a humorous manner. The self-authored description of the podcast was that it was aimed for those who "hate women, love women or have no opinion of women."

The media coverage of the debate around the podcast can be traced to an October article written by culture journalist Greta Thurfjell and published in Dagens Nyheter (DN), arguably the most prestigious newspaper in Sweden. In the article, the angle was "the forbidden allure of conservatism," and one of the women behind Della $Q$ was interviewed. She stated that the podcast was appealing to people who had "understood that it's not that dangerous to admit that men and women are different" and the topics of the podcast were referenced as being traditionally female, filling a gap in the media since "the typically feminine is frowned upon nowadays, or is at least not desirable" (Thurfjell 2018). The article sparked a larger debate about political ideology and gender roles, and whether there was a current backlash against feminism in Sweden. The popularity of the podcast would be referenced as an example of this backlash in the debate.

In the media coverage referencing Della $Q$ in particular, themes of the framing could be attributed to the critique and defence of the podcast, or meta-frames concerned with the media debate about the podcast. This controversy differed from the other cases in this study because it was not a single joke or humorous segment that was criticised, but an overarching tone or attitude displayed by the women in the podcast. They were referenced as being crude, making inappropriate jokes such as incest jokes, and mainly targeting other women with their humorous remarks. Overstepping social boundaries is where much pleasure in humour lies, and violation of norms can happen in several different ways (Billig 2005). It can be breaches of logic, language, or plays with the unseemly, but it can also be transgressions of what is expected, and clearly the women of Della $Q$ were somehow representatives of deviance from what was expected. This could be seen as a reflection of the enforcement function of humour, since it was occupied with norm transgressions, and also differentiation, since the women were portrayed as providing a political alternative to Swedish consensus culture. Even though the women behind Della $Q$ did not adhere to any political affiliation, the podcast was labelled as conservative in the media, and they were described as part of a new hot trend of young political conservatism. However, in the media coverage that was directly concerned with the podcast, a counternarrative to this categorisation was also prominent:

\footnotetext{
2 “About the podcast” from https://dellaq.libsyn.com/ Accessed 17 May 2019.
} 
But what Thurfjell describes is a play on certain aesthetic ideals, not a political conservatism. [...] Della $Q$ is a humour podcast, not a political podcast. That it has become a symbol of something conservative is very strange.

(Norrköpings Tidningar, 14 November 2018)

The critique in Della $Q$ is definitely coming from the right, but has no clear political purpose. They rather seem to fight the established consensus, and advocate for intellectual mobility. [...] It is refreshing in a time of intellectual conformity, regardless of whether you agree with them or not.

(SVT Nyheter, 26 October 2018)

The fact that Thurfjell's text in DN is at all considered norm-breaking might be more telling of the firm grip feminist, social-constructivist theories still have in Swedish publicity.

(Dagens samhälle, 3 December 2018)

The critics called the women of the podcast mean, provocative, and anti-feminist, and the defenders called them outspoken, honest, and sadly misunderstood. This was a debate for culture journalists and editorial writers. The frames were often problematising, complex, and meta - in the sense that most articles in the material referenced the media debate in itself as an entry point for the subject.

The other day Jens Liljestrand wrote about the popular women's podcast Della $Q$ and stated that what distinguishes the podcast is malevolence. [...] I had not heard Della $Q$ before, but after listening to a bunch of episodes I only partly agree with Liljestrand. It is not at all relentlessly malicious, however, the conversation has a constant undercurrent of cool high school girls who at any time can say anything about anyone outside the group and everyone is expected to laugh.

(Expressen, 21 November 2018)

This was perhaps the most literal description of the differentiation function found in all of the media material analysed in this study: the clear creation of in-groups and out-groups through the use of humour. The comparison to bullying was made repeatedly.

The media context was highly visible in the debate: Apart from the frame that focused on the debate as a result of a changing political landscape, there were also examples of framing the debate as the result of a changing media landscape. The controversy was in part attributed to the debate climate fostered on social media, where people form opinions based simply on headlines, or sharpen moderate critique for stronger impact. A question was raised if the critics had actually listened to the podcast. The media format of podcasting was mentioned as having specific circumstances, where conversations can, and should, be raw, sloppy, and unfiltered.

That is how it should be perceived: as a conversation between friends. But the internet has become some sort of semi-publicity, where each expression is treated as an official statement. Where everyone has learned to guard their tongues and weigh each word.

(Dagens Nyheter, 29 November 2018)

This could be said to correlate with the humour function's identification and clarification, with the defenders describing the humour as benign and politically non-transgressive. They pointed to a misunderstanding about what the podcast was meant to be and its intended audience. The defenders claimed the light-hearted, sometimes ironic and exaggerated discussions of the women on the podcast were taken literally, or overstated with regards to their political implications. The journalist behind the article that started the debate, Greta Thurfjell (aged 24) commented on the commotion in a follow-up article in DN. She wrote, "grown-ups shouldn't meddle with things they do not understand," and that all she heard when listening to the podcast was "regular girl talk." This reflection of a generational divide was another example of how the identification and differentiation functions depended on who was listening. 


\section{Discussion and conclusion}

The first and second research questions asked about the framings of the controversies and how they related to the humour functions. Emerging from these examples of media framing are three prevalent dimensions of transgressions: violations on a political level, violations on a social or moral level, and violations on a cultural level. All three controversies have political ramifications according to the media framing: controversy A is closely associated with parliamentary politics, controversy B is framed as a part of an international conflict, and controversy $\mathrm{C}$ is discussed as a political and ideological dispute. When it comes to the political level of the humorous transgressions, the framing was similar to framing of other kinds of Swedish political scandals, and enforcement and differentiation functions were clearly visible. Reactions showed the possibility of identifying with either the joker or the target of the joke dependent on political affiliation. There were also social or moral implications to all three cases. Here we see reflections of how the enforcement and differentiation functions are derived from superiority theory: There were references to bullying, exclusion, malevolence, crudeness, inappropriate displays of emotion, and a clear divide of "us" and "them," which also connected to the cultural level of transgression, mostly represented by controversy B, due to the focus on cultural differences between Swedes and the Chinese.

The results confirmed previous notions on how humour controversies through media framing can function as catalysts of debates (Lewis 2008: 15; Kessel \& Merziger 2012) and be amplified to be used as political assets (Davies 2008: 6). As in other humour scandals, such as the Danish cartoon crisis, the media dramatisation played out social divides of moral and political rifts, through the function of differentiation (Kuipers 2011). In these cases, the controversies lead to media debates on Chinese violations against human rights, feminism, the role of public service broadcasting media, freedom of speech, conservatism, racism, and the social media debate climate, among other topics. The humour transgressions served as starting points for a broader issue framing in the media, and the connection to humour gave it an emotional aspect where laughter, hurt, and offence were included aspects of the debates. There were frames in which being exposed to jokes at your expense was used as a defence or justification for rash behaviour and subsequent political statements.

The humour functions of identification, enforcement and differentiation were predominantly reflected in the material. Because this study was concerned with media framing of controversy, seeing evidence of enforcement was somewhat by design. Controversies arise from transgressions, and media news values tend to favour conflict over unity (Shoemaker 1987). Enforcement is about norm violations, and differentiation is about making alliances and distinctions. The latter is derived from both incongruity and superiority theory and stresses contradictions and differences between one social group and another (Meyer 2000: 321). Differentiation was in addition interestingly intertwined with the media context, which will be discussed further when addressing the third research question.

In the news media coverage, identification and clarification were somewhat expressed in defence of humorous content. Defenders stated that the humour was intended for an in-group, to poke fun at common traits and beliefs, although this failed to some extent. Clarification was the least prominent humour function in the framing. The traditional use of clarification is, for instance, to condense a political policy into a humorous line to get media coverage, and although there surely are examples of similar sound bites in the material, the function is supposed to focus on illuminating expected social behaviour and not norm violations (Meyer 2000: 319). Using clarification makes for a benign form of humour without a sense of correction, which is why it is considered to be uniting rather than dividing, and why it would be less visible in media coverage surrounding humorous transgressions. 
The findings exposed how closely connected the media context was to the controversies, which leads us to the third research question. Media fragmentation in general and social media in particular were to a significant degree highlighted as factors in the development of the controversies. Humour being taken out of context was described both from the aspect of media platforms, where the content was being moved from one media form to another, and with an emphasis on audience, where misunderstandings could occur due to fragmentation. This also interacted with humour functions. The findings revealed that by shifting the media context, the most uniting humour function of identification could be transformed into the most dividing humour function of differentiation. This was perhaps most clearly demonstrated by controversy B: the intent of the satire was a self-deprecating jab at Swedish ignorance, but by posting it out of context in Chinese social media, it read as an attack on the Chinese people. This has always been a consequence of the dualistic nature of humour - meaning that when humour is used for identification, when it increases cohesiveness within a group, it simultaneously creates differentiation by excluding people outside the group - but the addition of a new media context with different framing escalated the differentiation. According to the media coverage, the satirical segment shifted Chinese public opinion from a sense of us and them, where "them" meant the embarrassing Chinese tourists in the original news story, to an us and them where "them" meant insensitive Westerners in general and the Swedish people in particular. This adheres to a scholarly development in the sociology of humour, where one witnesses increased globalisation or cross-national diffusion of humour, sometimes with unexpected consequences (Kuipers 2014: 713).

In controversies $\mathrm{A}$ and $\mathrm{C}$, the media context also played a vital role. It mattered partly by lack of contextualisation when news spread on social media, and partly by affecting audience expectations via misinterpretation of what the content "was" or was intended to be. In an increasingly fragmented media environment, controversies and debates can take on lives of their own, and humorous intent can transform from uniting to dividing outside the hands of the creators. De-contextualisation - or re-contextualisation - creates new narratives and frames around the humour, and therefore gives new discursive reasons for failure and/or backlash. This is a development that is not likely to subside in our hybrid media landscape.

\section{References}

Aalberg, T., Strömbäck, J. \& De Vreese, C. H. (2011). 'The framing of politics as strategy and game: A review of concepts, operationalisations and key findings'. Journalism 13 (2), pp. 162-178.

Abel, A. D. \& Barthel, M. (2013). 'Appropriation of mainstream news: How Saturday Night Live changed the political discussion'. Critical Studies in Media Communication 30 (1), pp. 1-16.

Ammitzbøll, P. \& Vidino, L. (2007). 'After the Danish cartoon controversy'. Middle East Quarterly 14 (1), pp. 3-11.

Apte, M. L. (1985). Humour and Laughter: An Anthropological Approach. Ithaca: Cornell University Press.

Attardo, S. (1994). Linguistic Theories of Humour. Berlin: Mouton de Gruyter.

Attardo, S. (2008). 'Semantics and pragmatics of humour'. Language and Linguistics Compass, 2 (6), pp. 1203-1215.

Basu, S. (1999). 'Dialogic ethics and the virtue of humour'. Journal of Political Philosophy 7 (4), pp. 378-403.

Bell, N. \& Attardo, S. (2010). 'Failed humour: Issues in non-native speakers' appreciation and understanding of humour'. Intercultural Pragmatics 7, p. 423. 
Bell, N. D. (2009). 'Responses to failed humour'. Journal of Pragmatics 41 (9), pp. 1825-1836. Berger, A. A. (1999). An Anatomy of Humour. New Brunswick: Transaction.

Billig, M. (2005). Laughter and Ridicule: Towards a Social Critique of Humour. London: Sage. Borah, P. (2011). 'Conceptual issues in framing theory: A systematic examination of a decade's literature'. Journal of Communication 61 (2), pp. 246-263.

Bruun, H. (2012). 'Political satire in Danish television: Reinventing a tradition'. Popular Communication 10 (1-2), pp. 158-169.

Bryant, J. \& Miron, D. (2004). 'Theory and research in mass communication'. Journal of Communication 54 (4) pp. 662-704.

Chapel, G. W. (1978). 'Humor in the White House: An interview with presidential speechwriter Robert Orben'. Communication Quarterly 26 (1), pp. 44-49.

Dahl, J. M. R. (2019). 'From the club stage to the national scene: How mass media interpreted two comedians as important immigrant voices'. Javnost - The Public 26 (2), pp. 210-224.

Davidsson, P., Palm, M. \& Melin Mandre, Å. (2018). Svenskarna och Internet 2018. Retrieved 25 May 2019 from https://internetstiftelsen.se/docs/Svenskarna_och_internet_2018.pdf

Davies, C. (2008). 'The Danish cartoons, the Muslims, and the new battle of Jutland', in: Lewis, P., Davies, J. C. H., Kuipers, G., Martin, R. A., Oring, E. \& Raskin, V. (eds.), 'The Muhammad cartoons and humour research: A collection of essays'. Humour: International Journal of Humour Research 21 (1), pp. 2-7.

De Vreese C. H., Peter, J. \& Semetko, H. A. (2001). 'Framing politics at the launch of the Euro: A cross-national comparative study of frames in the news'. Political Communication 18 (2), pp. 107-122.

De Vreese, C. H. (2005). 'News framing: Theory and typology'. Information Design Journal \& Document Design, 13 (1), pp. 48-59.

Douglas, M. (1999). Implicit Meanings: Selected Essays in Anthropology. London: Routledge.

Duncan, H. D. (1962). Communication and Social Order. New York: Bedminster Press.

Ekström, M. \& Johansson, B. (2008). 'Talk scandals'. Media, Culture \& Society 30 (1), pp. 61 79.

Entman, R. M. (1993) 'Framing: Toward clarification of a fractured paradigm'. Journal of Communication 43 (4), pp. 51-58.

Hallahan K. (1999). 'Seven models of framing: Implications for public relations'. Journal of Public Relations Research 11 (3), pp. 205-242.

Hariman, R. (2008). 'Political parody and public culture'. Quarterly Journal of Speech 94 (3), pp. 247-272.

Hellström, A., Nilsson, T. \& Stoltz, P. (2012). 'Nationalism vs. nationalism: The challenge of the Sweden Democrats in the Swedish public debate'. Government and Opposition 47 (2), pp. 186-205.

Higgie, R. (2017). 'Public engagement, propaganda, or both? Attitudes toward politicians on political satire and comedy programmes'. International Journal of Communication 11, pp. 930-948.

Jones, J. P. (2013). 'Parody, performativity, and play'. A Companion to New Media Dynamics, pp. 396-406.

Kessel, M. \& Merziger, P. (2012). The Politics of Humour: Laughter, Inclusion, and Exclusion in the Twentieth Century. Toronto: University of Toronto Press.

Klausen, J. (2009). The Cartoons that Shook the World. New Haven: Yale University Press.

Kohlbacher, F. (2006). 'The use of qualitative content analysis in case study research'. Forum Qualitative Sozialforschung/Forum: Qualitative Social Research; Learning about Risk, 7 (1).

Kuipers, G. (2006). Good Humour, Bad Taste: A Sociology of the Joke. Berlin: Mouton de Gruyter. 
Kuipers, G. (2008). 'The sociology of humour'. In Raskin, V. (ed.), The Primer of Humor Research Vol. 8. Berlin, Boston: De Gruyter Mouton. pp. 361-398.

Kuipers, G. (2011). 'The politics of humour in the public sphere: Cartoons, power and modernity in the first transnational humour scandal'. European Journal of Cultural Studies, 14 (1), pp. 63-80.

Kuipers, G. (2014). 'Sociology'. In Attardo, S. (ed.), Encyclopaedia of Humor Studies Vol 2, Thousand Oaks: Sage Publications.

Kumar, S. \& Combe, K. (2015). Political Parody and Satire as Subversive Speech in the Global Digital Sphere. London: Sage UK.

Lewis, P. (2008). 'The Muhammad cartoon conflict: Implications for humour research and advocacy', in: Lewis, P., Davies, J. C. H., Kuipers, G., Martin, R. A., Oring, E. \& Raskin, V. (eds.), 'The Muhammad cartoons and humour research: A collection of essays'. Humor: International Journal of Humor Research 21 (1), pp. 11-16.

Lichtenstein, D., Esau, K., Pavlova, L., Osipov, D. \& Argylov, N. (2018). 'Framing the Ukraine crisis: A comparison between talk show debates in Russian and German television'. International Communication Gazette 81 (1), pp. 66-88.

Lynch, O. H. (2002). 'Humorous communication: Finding a place for humour in communication research'. Communication Theory 12 (4), pp. 423-445.

Mancini, P. (2013). 'Media fragmentation, party system, and democracy'. The International Journal of Press/Politics 18 (1), pp. 43-60.

Marra, J. (2018). 'Make comedy matter: Ernst Cassirer on the politics and morality of humour'. The European Journal of Humour Research 6 (1), pp. 162-171.

Mayring, P. (2014). Qualitative Content Analysis: Theoretical Foundation, Basic Procedures and Software Solution. Klagenfurt: Sage.

McGhee, P. M. \& Goldstein, J. H. (1972). The Psychology of Humour: Theoretical Perspectives and Empirical Issues. New York: Academic Press.

Meyer, J. C. (2000). 'Humour as a double-edged sword: Four functions of humour in communication'. Communication Theory 10 (3), pp. 310-331.

Michaud Wild, N. (2015). 'Dumb vs. fake: Representations of Bush and Palin on Saturday Night Live and their effects on the journalistic public sphere'. Journal of Broadcasting \& Electronic Media 59 (3), pp. 494-508.

Morreall, J. (1983). Taking Laughter Seriously. Albany: State University of New York.

Mulkay, M. J. (1988). On Humour: Its Nature and its Place in Modern Society. Cambridge: Polity Press.

Ödmark, S. (2018). 'Making news funny: Differences in news framing between journalists and comedians', Journalism. https://doi.org/10.1177/1464884918820432

Palmer, J. (1994). Taking Humour Seriously. London: Routledge.

Patterson, T. E. (1993). Out of Order. New York, N.Y.: Knopf.

Peifer, J. T. (2013). 'Palin, Saturday Night Live, and framing: Examining the dynamics of political parody'. The Communication Review 16 (3), pp. 155-177.

Plato. (1961). The Collected Dialogues of Plato, Including the Letters. New York: Princeton University Press.

Quirk, S. (2015). Why Stand-up Matters: How Comedians Manipulate and Influence. London: Bloomsbury.

Raskin, V. (1985). Semantic Mechanisms of Humor. Dordrecht: Reidel.

Rose, F. (2014). The Tyranny of Silence. Washington: CATO Institute Press.

Sallinen, J. (2018, August 30). 'Detta har hänt: Vikthån-då ville Åkesson skrota P3'. Svenska Dagbladet. Retrieved 17 January 2021 from https://www.svd.se/detta-har-hant-vikthan-da-ville-akesson-lagga-ner-p3 
Scheufele, D. A. \& Tewksbury, D. (2007). 'Framing, agenda setting, and priming: The evolution of three media effects models'. Journal of Communication 57 (1), pp. 9-20.

Shoemaker, P. J. (1987). 'Building a theory of news content'. Journalism Monographs 103.

Stigsson, H. (2018, August 30). 'Dags att hyfsa debatten'. Norrköpings Tidningar. Retrieved 17 January 2021 from https://nt.se/asikter/ledare/dags-att-hyfsa-debatten-om5436965.aspx

Strömbäck, J. \& Dimitrova, D. V. (2006). 'Political and media systems matter: A comparison of election news coverage in Sweden and the United States'. Harvard International Journal of Press/Politics 11 (4), pp. 131-147.

Syvertsen, T., Mjøs, O. J., Enli, G. S. \& Moe, H. (2014). The Media Welfare State: Nordic Media in the Digital Era. Ann Arbor: University of Michigan Press.

Tang, A. (2018, September 25). 'Det är ju bara på skämt-och vi kineser saknar tydligen humor'. SVT Opinion. Retrieved 17 January 2021 from https://www.svt.se/opinion/det-ar-ju-barapa-skamt-och-vi-kineser-saknar-tydligen-humor

Thompson, J. B. (2000). Political Scandal: Power and Visibility in the Media Age. Cambridge: Polity Press.

Thurfjell, G. (2018, October 24). 'Huskvinnans återkomst-och konservatismens förbjudna lockelse'. Dagens Nyheter. Retrieved 17 January 2021 from https://www.dn.se/kulturnoje/kulturdebatt/huskvinnans-aterkomst-och-konservatismens-forbjudna-lockelse/

Wadbring, I. \& Ödmark, S. (2014). Delad Glädje är Dubbel Glädje: En Studie om Nyhetsdelning i Sociala Medier. Sundsvall: Mittuniversitetet.

Weitz, E. (2016). 'Humour and social media'. The European Journal of Humour Research 4 (4), pp 1-4.

Ziv, A. (1984). Personality and Sense of Humour. New York: Springer. 